Review

\title{
Biotechnological Approaches for Production of High Value Compounds from Bread Waste
}

\author{
${ }^{1}$ Saima Haroon, ${ }^{2}$ Anu Vinthan, ${ }^{3}$ Leonardo Negron, ${ }^{2}$ Shantanu Das and ${ }^{1}$ Aydin Berenjian \\ ${ }^{I}$ School of Engineering, Faculty of Science and Engineering, The University of Waikato, Hamilton, New Zealand \\ ${ }^{2}$ Goodman Fielder Limited, Auckland, New Zealand \\ ${ }^{3}$ Callaghan Innovation, 69 Gracefield Road, Lower Hutt, New Zealand
}

Article history

Received: 25-05-2016

Revised: 14-06-2016

Accepted: 14-06-2016

\section{Corresponding Author:}

Aydin Berenjian

School of Engineering, Faculty of Science and Engineering,

The University of Waikato,

Hamilton, New Zealand

Tel: +64 78585119

Email: aydin.berenjian@waikato.ac.nz

\begin{abstract}
A growing global population has led to an increasing demand for food processing industries and consequently the generation of large amounts of food waste. This problem has intensified due to slow progress in the development of effective waste treatment and disposal strategies. Food waste such as bread waste is a reservoir of complex carbohydrates, proteins and lipids which have the potential to be reused in fermentation processes. In this regard, bread waste has been used for the production of a variety of bio-products including ethanol, methane, lactic acid, succinic acid, amylase and protease. This review provides an overview of the previous works in the literature on the utilization of bread waste and the different bio processing approaches to produce a higher value products. Recommendations are also provided for areas of future research.
\end{abstract}

Keywords: Bread Waste, Fermentation, By-Products, Biomass, Nutraceutical Products

\section{Introduction}

Food waste is produced throughout the food life cycle and occurs at different stages of production, processing, retailing and consumption (Uçkun Kiran et al., 2014). The amount of food waste has increased in the last 25 years due to population and economic growth. The amount of food waste production in Asian countries was 278 million tonnes in 2005; this figure is expected to increase 1.5 fold by 2025 reaching 416 million tonnes (Uçkun Kiran et al., 2014). In the European Union, food waste generation is anticipated to rise from 89 million tonnes in 2006 to about 126 million tonnes in 2020 (Pham et al., 2015). The major categories of food wastes are meat, fruit, vegetables and bakery products. It is estimated in New Zealand, more than 122,500 tons of food is thrown away each year which is enough to feed almost 263,000 people, for 12 month (SIN, 2015). Food waste is particularly problematic as it has a significantly high organic content (Mekjinda and Ritchie, 2015), which causes severe environmental and subsequent health problems (Fig. 1) (WRT, 2011).

Based on the Food and Agricultural Organization (FAO) report, food waste not only causes huge economic losses but also results in significant damage to natural resources such as climate, water, land and biodiversity (FAO, 2012). Without a proper treatment, one ton of food waste can result in the emission of 4.5 tonnes
(Uçkun Kiran et al., 2015) of organics into landfills (Kosseva, 2009; FAO, 2012). Reducing the amount of food waste, therefore, would have significant financial and environmental benefit.

\section{Bread Waste}

Bread is among the major food waste in many countries around the world. It is estimated that 1.2 million tonnes of bread wasted every year globally. Wastage occurs at bakeries, retail outlets with leftovers and consumer households. It is estimated that 407,000 tonnes of bakery waste is produced in the UK every year, which is approximately $15 \%$ of the annual UK bread production (Melikoglu and Webb, 2013). This figure is very similar in many countries around the world including New Zealand. Bakery food comprises $10 \%$ of all the food waste (20,575 tonnes per annum) (Fig. 2). These include white bread, mixed grain bread, wheat meal bread and bread roll/baguette (Waste MINZ, 2015).

Typically $100 \mathrm{~g}$ of bread contains around $50 \mathrm{~g}$ carbohydrate (47 $\mathrm{g}$ in the form of starch), $9 \mathrm{~g}$ protein, 5 $\mathrm{g}$ fat, $0.1 \mathrm{~g}$ phosphorus, $2.3 \mathrm{~g}$ ash and $28.7 \mathrm{~g}$ water. Bread has a short shelf life (4-7 days) and various physical and chemical changes occur during its storage. These include major changes in physiochemical characteristics that impact on taste and aroma (Melikoglu and Webb, 2013; Alibardi and Cossu, 2016). 


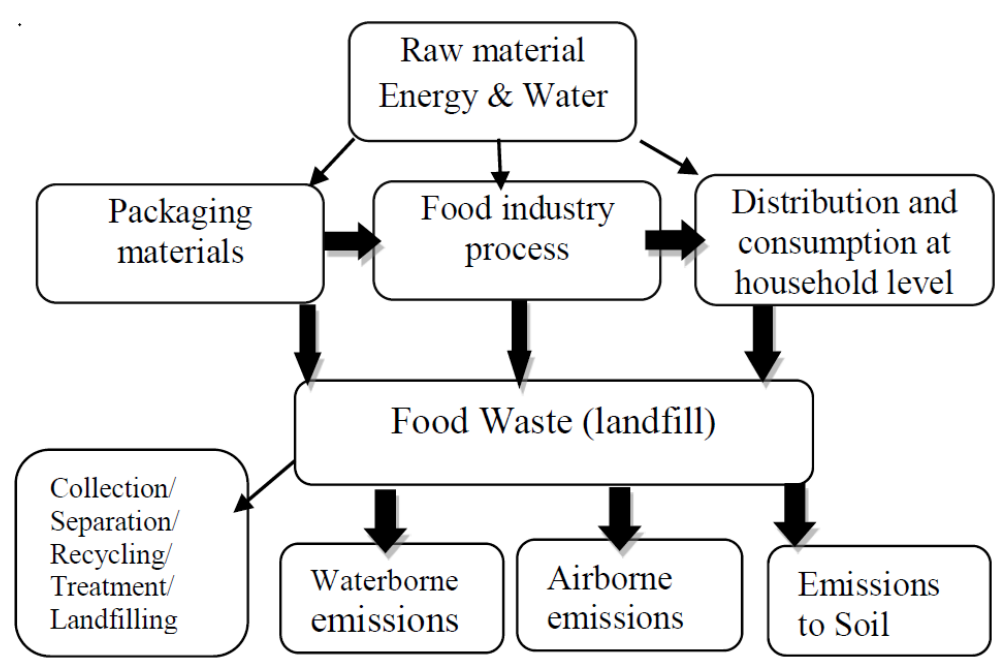

Fig. 1. Food industry waste in the food supply chain, pollutant emissions in air, water and soil (Mekjinda and Ritchie, 2015)

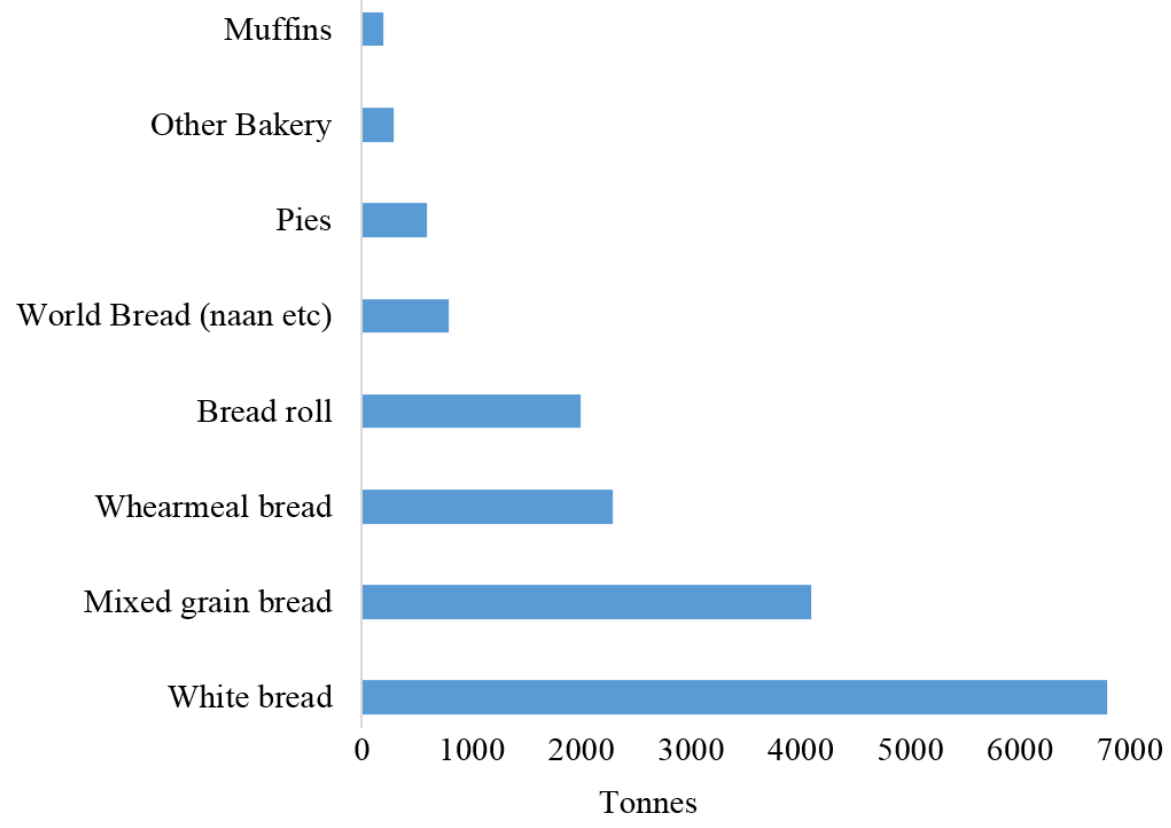

Fig. 2. Bakery waste in tonnes per annum in New Zealand (Waste MINZ, 2015)

Large quantities of bread are discarded due to staling which create economic and environmental problems. Therefore, there is a significant need to develop processes to reduce the associated problems with bread waste formation.

\section{Bioprocess Approaches}

Fermentation is a biotechnological process in which complex organic compounds such as carbohydrates and proteins are utilized by fungi or bacteria. During fermentation microorganisms convert nutrients into end metabolites (Leroy and De Vuyst, 2004). Fermentation has been widely used for the production of a wide variety of compounds. Over the years, fermentation techniques have gained immense importance in waste treatment approaches due to their economic and environmental advantages (Olempska-Beer et al., 2006; Subramaniyam and Vimala, 2012).

Two types of fermentation processes namely Solid State Fermentation (SSF) and submerged or Liquid State Fermentation (LSF) have been dominantly used by researchers. SSF process occurs in low levels of free water and the substrates are solid and insoluble in nature such as grains, wheat bran and vegetables. Due to the low level of free water, this process is more suitable for mycelial fungi than bacteria. SSF process is a simple and 
cost effective. It requires lower capital investments and can lead to lower ongoing expenditure. Therefore, SSF can improve economic feasibility of the biotechnological processes by offering waste reduction in design and operation (Kosseva, 2013).

LSF is a controlled process which consists of growing cells in a liquid broth. LSF involves soluble feed stocks since there is more water and less substrates. Moreover, process control and scale up are well established as compared to SSF (Subramaniyam and Vimala, 2012). To date, both SSF and LSF approaches have been used for bread waste utilization. The sections below describe the recent and previous work progresses in more details.

\section{Utilization of Bread Waste}

The various approaches adopted by different researchers in the area of waste bread utilization are summarized in Table 1. The earliest work on the utilization of bread waste was carried out by Nakano and Yoshida (1977). They used crushed waste bread pieces mixed with molasses, cellulolytic, proteolytic and saccharifying enzymes. The mixture was incubated at $50^{\circ} \mathrm{C}$ for $75 \mathrm{~h}$ to produce a glucose rich syrup which was used as a sugar substitute (Melikoglu and Webb, 2013). Berghofer et al. (1995) developed a process for syrup production from waste bread by using hot mash material with malt and enzymatic hydrolysis processes. Daigle et al. (1999) also conducted a fermentation on waste bread crumbs for the production of aroma compounds. Fermentation was carried out with 35\% white bread crumb and $65 \%$ water, using Geotrichum candidum ATCC 62217 in Erlenmeyer flasks at $30^{\circ} \mathrm{C}$ and $300 \mathrm{rpm}$. Doi et al. (2009) have demonstrated the feasibility of bio-hydrogen production from waste bread by using hydrogen-producing bacteria Megasphaera elsdenii and Clostridium species.

Bioethanol has recently attracted much attention as an alternative resource to fossil fuels. The global market for bioethanol has entered a phase of rapid transitional growth. Many countries around the world are shifting their focus toward renewable sources for power production because of depleting crude oil reserves. Ethanol has high potential as a valuable replacement for gasoline in the transport fuel market. Kumar et al. (1998) demonstrated that bakery waste can be utilized to produce ethanol. The bakery waste which included bread, buns, cake and donuts were ground and mixed with water and commercial $\alpha$-amylase and glucoamylase to hydrolyse the starch. This hydrolysate from starch was then used for ethanol fermentation by using ethanol tolerant Saccharomyces cerevisiae. Kawa-Rygielska and Petrzak (2011) also investigated the possibility of using bakery waste as a raw material for ethanol fermentation by Saccharomyces cerevisiae.

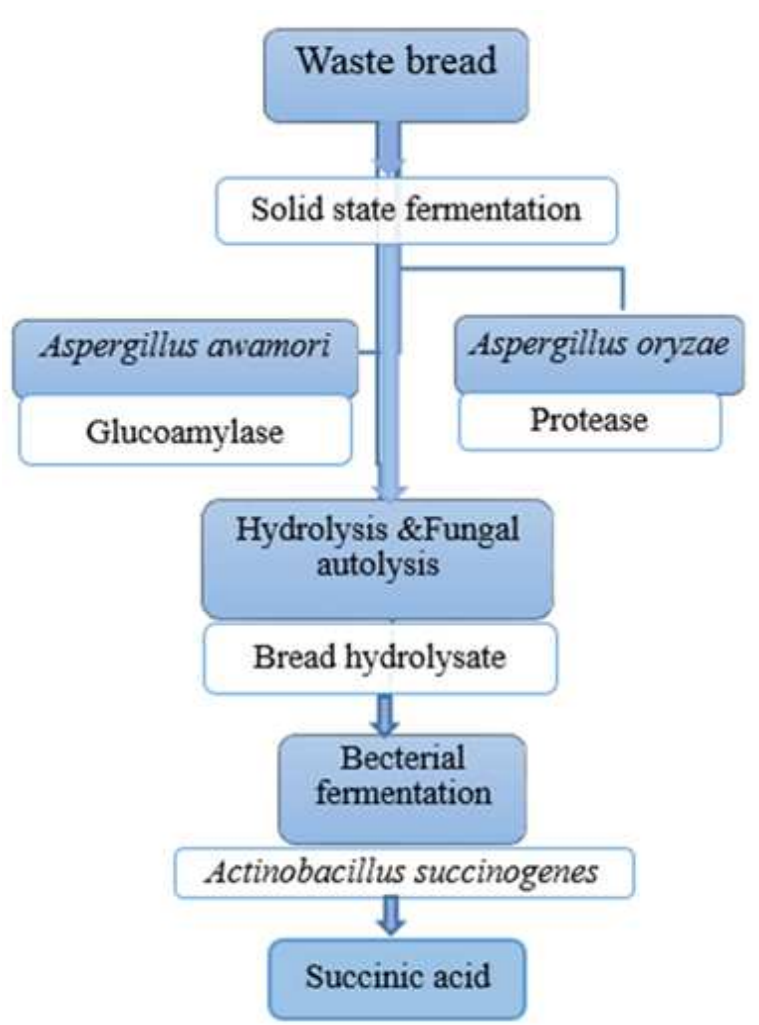

Fig. 3. Process flow diagram of the production of succinic acid from bread waste (Leung et al., 2012)

Table 1. Summary of bio processing research in the utilization of bread waste to value added products (Melikoglu and Webb, 2013)

\begin{tabular}{ll}
\hline Publication & End product \\
\hline Nakano and Yoshida (1977) & Glucose rich syrup \\
Martin (1984) & Ethanol \\
Menge et al. $(1986)$ & Lactic acid \\
Berghofer et al. $(1995)$ & Glucose rich syrup \\
Oda et al. (1997) & Lactic acid \\
Kumar et al. $(1998)$ & Ethanol \\
Meuser (1998) & Ethanol \\
Daigle et al. $(1999)$ & Aroma compound \\
Asghar et al. (2002) & a-amylase production \\
Yahagi et al. $(2003)$ & Starch substitute \\
Yamashita and Miwa (2003) & Methane \\
Maeda et al. (2004) & Ethanol \\
Murase and Yoshino (2005) & Sugar solution \\
Melikoglu et al. (2013) & Enzyme and ethanol \\
Doi et al. (2009) & Bio-hydrogen \\
Leung et al. (2012) & Succinic acid \\
\hline
\end{tabular}

The yeast for ethanol production was the same as the one used for leavening bread (Kawa-Rygielska and Petrzak, 2011). Utilization of waste bread, for bioethanol production is an innovative solution for recycling bread waste and at the same time reducing its environmental impact in an eco-friendly and profitable way. 
Table 2. List of food grade and probiotic microorganisms and their final products

Microorganism

Lactococcus lactis

Lactobacillus brevis + Protease

Lactobacillus gasseri

Lactobacillus plantarum

+ Lactococcus. lactis

Lactobacillus reuteri

Lactobacillus sanfranciscensis

Lactobacillus mindensis

Lactobacillus acidifarinae

Lactobacillus zymae sp.nov

Lactobacillus plantarum

Lactobacillus rhamnosus

Lactobacillus bulgaricus

Bifidobacterium lactics

Bifidobacterium bifidum

Bifidobacterium infantis

Bifidobacterium longum

Rhizobus oligosporus

Saccharomyces cerevisiae var. boulardii

Aspergillus awamori (fungi)

Aspergillus niger

Aspergillus oryzae

Rhizopus oryzae

Bacillus coagulans GBI-30, 6086 Bacillus subtilis (natto)

Saccharomyces boulardii

Streptococcus thermophilus

Leuconostoc

Monascus purpureus

Enterococcus faecium

Gluconacetobacter xylinus

Lactobacillus buchneri

+ Lactobacillus diolivorans

Actinobacillus succinogenes

Candida utilis

Candida milleri

Lactobacillus sporogenes

Lactobacillus rhamnosus

Lactobacillus casei

Lactobacillus plantarumtarum

Bifidobacterium breve

Propionibacterium sp.

Geotrichum candidum

Mixture of Lactobacillus and yeasts species mainly Saccharomyces and Candida

(Microorganisms of

sourdough sponges)
Final metabolite

Lactic acid, organic acids, hydrogen peroxide, diacetyl, Exo-Polysaccharides (EPS),

Lactate (DL) lactones (flavour), Guanosine Triphosphate (GTP) cyclohydrolase enzymes,

glucosidases, proteases and amylases (Arendt et al., 2007)

$\gamma$-Aminobutyric Acid (GABA) $\alpha$-acetolactate, esters (fruity aroma), diacetyl (buttery flavor), vitamin $\mathrm{B}_{12}, \mathrm{~B}_{11}$, Folate (Sybesma et al., 2003), alanine, low calorie sugar (Hugenholtz and Smid, 2002), glutamate decarboxylase and tagatose production (Bhanwar et al., 2013). $\gamma$-Aminobutyric Acid (GABA) and peptide (Peñas et al., 2015). Vitamins D and K DL-lactic acid, gives texture and nutrition (Fujimura et al., 2012).

L-alanine (amino acid), lactate

Low-calorie sweetener, such as mannitol, sorbitol, GABA (Coda et al., 2010).

Cobalamin (vitamin $\mathrm{B}_{12}$ ), probiotic oligo and poly-saccharides (Schwab et al., 2008)

Exo-Polysaccharide (EPS), lactate, acetate, ethanol and $\mathrm{CO}_{2}$ (Ganzle et al., 1998)

DL-lactate and lysine-D-iso-asparagine (Ehrmann et al., 2003).

DL-lactic acid, acetic acid and ethanol. Arginine is de-aminated to citrulline

( $\alpha$-amino acid) (Vancanneyt et al., 2005)

Lactolin, natural antibiotic. L-lysine, anti-viral amino acid, peptides and antioxidants

(Rick Swartzburg, 2009)

Vanillin (flavour compound), lactic acid (Ganeden BC 30 Probiotics, 2015)

Folate, acetaldehyde, diacetyl, bacteriocins.

Lactulose, inulin, galactooli gosaccharides, glucose and variety of proteins.

Lactate $(\mathrm{L}+)$, acetate, vanillin (flavour compound) acetic acid, ethanol and formic acid

(Jo Panyko, 2015)

Acetic acid, with lactic and formic acid. Vitamin $B$, folate thiamine $\left(\mathrm{B}_{1}\right)$, nicotinic acid

(a $\mathrm{B}_{3}$ derivative) (Ganeden BC 30 Probiotics, 2015).

Acetic acid, ethanol, formic acid and succinic acid

Vitamin $\mathrm{B}_{12}$ and niacin, free amino acids (isoleucine, leucine, lysine, valine, glycine,

histidine, tyrosine) and GABA (Knorr, 1998).

Aromatic flavours compound, 2- and 3-methylbutanol, methyl-propanoic acid,

3-methylbutanoic acid and 2-phenylethanol (in sourdough bread) (Hansen and Schieberle,

2005). Protease (van der Aa Kühle et al., 2005)

Multi-enzyme solution (Glucoamylase, phosphatase, xylanase and protease) (Melikoglu et al., 2013)

Citric acid. $\beta$-Glucanase, glucoamylase, glucose-oxidase and lactase (Olempska-Beer et al., 2006)

Glucoamylase, lactase, amylase, maltoryzine and violacetin (Olempska-Beer et al., 2006)

Lactic acid and fumaric acid (Skory, 2004). Aroma, aspartic proteinase, glucose oxidase,

lipase and laccase (Olempska-Beer et al., 2006)

L-lactic acid

Protease, $\alpha$-amylase, vitamin $\mathrm{K}$, vitamin $\mathrm{B}_{12}$, Poly glycolic acid (PGA)

Serine, protease and phosphatase that destroys the endotoxin (Kelesidis and Pothoulakis, 2012).

Lactase enzyme, folate, Lactone (buttery and fruity flavour) esters (cyclic) of hydroxyl

acids, diacetyl and acetaldehyde.

Lactic acid, mannitol (antioxidant). Flavour, lactate $(\mathrm{L}+)$, diacetyl and acetaldehyde

(Hugenholtz and Smid, 2002).

Lovastatin, identical to monacolin $\mathrm{K}$

Bacteriocins, enterocin A, enterocin B and enterocin $\mathrm{P}$

Acetate, gluconate, acetaldehyde, $\mathrm{CO}_{2}$ (Zhang et al., 2014)

Flavour, lactate, lactic acid, acetic acid and propionic acid (Zhang et al., 2010)

Succinic acid (Zheng et al. 2009). Formate and acetate in high concentrations.

Lipase and invertase, fatty acids, pyridoxin, (vitamin $\mathrm{B}_{6}$ ), biotin (vitamin $\mathrm{B}_{7}$ ) and single

cell protein (Bourdichon et al., 2012).

Flavour and texture, Lipases, lactate, acetate, ethanol and $\mathrm{CO}_{2}$ (Vigentini et al., 2014)

Lactic-acid

Exo-polysaccharides (GGISL5 and LCISL3). Pili proteins (SpaCBA) and a sortase.

$\beta$-galactosidase, glycolytic enzymes and able to hydrolyse carbohydrates other than lactose. Amino acids with new beneficial peptides. Lactate, acetate, acetate kinase, pyruvate oxidase

Fructose, lactate and acetate

Vitamin B12, folate

Aroma compounds, ethanol, ethyl acetate, ethyl 2-utenoate, ethylbutyrate, ethyl

propionate, ethyl esters, 2-hexenoic acid and propanol-1

Flavour and aroma compounds mainly acetic acid, ethanol, 1-propanol, 2-methyl-1-

propanol, ethyl acetate, 3-methyl-1-butanol, 2-methyl-1-butanol, 1-pentanol, 2-methyl-

1-pentanol, 1-hexanol, 3-hexen-1-ol, 1-heptanol, 1-octanol acetaldehyde 3-methyl-1-

butanal 2-methyl-1-butanal hexanal, 3-methyl-hexanal, heptanal trans-2-heptenal

octanal nonanal benzaldehyde diacetyl, hexane, heptane, octane (Salim-ur-Rehman et al.,

2006). Organic acids, niacin, riboflavin, vitamin e, vitamins $b_{1}-b_{6}, b_{12}$, folate, thiamine. 
Oda et al. (1997) investigated the production of lactic acid from discarded bread (crust) by using an amylolytic bacterium. The researchers demonstrated that the addition of $2 \%$ yeast extract in the medium containing $3.58 \%$ bread crust caused maximum acid production (Melikoglu and Webb, 2013). The major breakthrough in this research was the conversion of the starch in bakery waste to lactic acid without supplementing starch-degrading enzymes. Leung et al. (2012) reported the successful production of succinic acid through the fermentation of waste bread pieces. A novel bio-refinery concept was developed by utilizing waste bread as a sole nutrient source for the production of a nutrient rich feedstock for succinic acid production by Actinobacillus succinogenes.

The waste bread was treated by two stage SSF processes: One to produce starch-degrading enzymes and the other to produce proteases. The enzymes were then used to hydrolyse the remaining fraction of the bread waste, as shown in Fig. 3 (Leung et al., 2012). In this process, Aspergillus awamori and Aspergillus oryzae produce enzyme complexes rich in amylolytic and proteolytic enzymes, respectively. The resulting fermentation outflow was added directly to the bread suspension to generate a hydrolysate containing over $100 \mathrm{~g} \mathrm{~L}^{-1}$ glucose and $490 \mathrm{mg} \mathrm{L}^{-1}$ free amino nitrogen (Leung et al., 2012).

The bread hydrolysate was used as the sole feedstock for $A$. succinogenes fermentation, which led to the production of $47.3 \mathrm{~g} \mathrm{~L}^{-1}$ succinic acid. This corresponds to an overall yield of $0.55 \mathrm{~g}$ succinic acid per $\mathrm{g}$ of bread. This is the highest reported succinic acid yield as compared to the other reported food waste-derived media. The proposed process could be potentially utilized to transform no-value food waste into value added product, succinic acid (Leung et al., 2012).

A summary of the various approaches (enzymatic hydrolysis, ethanol and lactic acid fermentation) adopted by different researchers in the area of waste bread utilization are summarized in Table 1.

\section{Future Trends and Prospects}

There is a global desire to divert bread waste from landfill, due to multiple objectives such as limited landfill capacity and increasing cost and numerous side effects such as greenhouse gasses generations. In the recent years, bio processing technologies have made a significant progress to address the challenges associated with bread waste formation. To date, variety of products including ethanol, methane, lactic acid, succinic acid, amylase and protease are generated by fermentation. However, many of these processes are not cost-effective and operationally feasible. Therefore, there is still a need for more sustainable and efficient technologies to enhance the plant profitability from the bread waste bioconversion.

The use of non-pathogenic and non-toxicogenic multifunctional microorganisms with the ability to produce valuable and high-priced metabolites such as vitamins and bioactive peptides can be seen as a novel approach. Potent microorganisms that can be used for production of these value added products are tabulated under Table 2. These microorganisms are suitable for large-scale industrial fermentation as they possess a high ability to survive the harsh processing conditions (Hugenholtz and Smid, 2002; Desmond et al., 2004; Smith and Jones, 2012; Perricone et al., 2014). Among these microbial sources, lactic acid bacteria seem to be the most important industrial microorganisms. During fermentation, lactic acid bacteria produce a wide range of value added secondary metabolites, some of which have been associated with significant health-promoting properties (NS, 1999; Holzapfel et al., 2001; Sybesma et al., 2003; Leroy and De Vuyst, 2004). In this regard, biosynthesis of antimicrobial substances, aromatic compounds and vitamins by lactic acid bacteria provides an attractive approach for future research trends.

\section{Conclusion}

With the advantages of biotechnological processes, microbial strains have been shown to have the ability to convert bread waste into a variety of products. To date, ethanol, methane, lactic acid, succinic acid, amylase and protease have been successfully produced by the SSF and LSF methods. However, there is still a need for innovative and more sustainable bioprocesses to address the issues associated with waste generation and low recycling rates.

\section{Acknowledgement}

The authors would like to thank the funding support from the MBIE contract under the collaboration title Bioresource Processing Alliance (BPA 130).

\section{Author's Contributions}

All authors equally contributed in this work.

\section{Ethics}

This article is original and contains unpublished material. The corresponding author confirms that all of the other authors have read and approved the manuscript and no ethical issues involved.

\section{References}

Alibardi, L. and R. Cossu, 2016. Effects of carbohydrate, protein and lipid content of organic waste on hydrogen production and fermentation products. Waste Manage. 47: 69-77.

DOI: 10.1016/j.wasman.2015.07.049 
Arendt, E.K., L.A. Ryan and F. Dal Bello, 2007. Impact of sourdough on the texture of bread. Food Microbiol., 24: 165-174.

DOI: $10.1016 /$ j.fm.2006.07.011

Asghar, M., U. Azhar, S. Rafiq, M.A. Sheikh and M.J. Asad, 2002. Production of $\alpha$-amylase by Arachniotus sp. using waste bread medium. Int. J. Agric. Biol., 4: 26-28.

Berghofer, E., G. Schleining and G. Matzner, 1995. Production of syrup out of waste bread. Nutrition, 19: 603-610.

Bhanwar, S., M. Bamnia, M. Ghosh and A. Ganguli, 2013. Use of Lactococcus lactis to enrich sourdough bread with $\gamma$-aminobutyric acid. Int. J. Food Sci. Nutr., 64: 77-81.

DOI: $10.3109 / 09637486.2012 .700919$

Bourdichon, F., S. Casaregola, C. Farrokh, J.C. Frisvad and M.L. Gerds et al., 2012. Food fermentations: Microorganisms with technological beneficial use. Int. J. Food Microbiol., 154: 87-97.

DOI: $10.1016 /$ j.ijfoodmicro.2011.12.030

Coda, R., C.G. Rizzello and M. Gobbetti, 2010. Use of sourdough fermentation and pseudo-cereals and leguminous flours for the making of a functional bread enriched of $\gamma$-Aminobutyric Acid (GABA). Int. J. Food Microbiol., 137: 236-245.

DOI: 10.1016/j.ijfoodmicro.2009.12.010

Daigle, P., P. Gélinas, D. Leblanc and A. Morin, 1999. Production of aroma compounds by Geotrichum candidum on waste bread crumb. Food Microbiol., 16: 517-522. DOI: 10.1006/fmic.1999.0269

Desmond, C., G.F. Fitzgerald, C. Stanton and R.P. Ross, 2004. Improved stress tolerance of GroESLoverproducing Lactococcus lactis and probiotic Lactobacillus paracasei NFBC 338. Applied Environ. Microbiol., 70: 5929-5936. DOI: 10.1128/AEM.70.10.5929-5936.2004

Doi, T., H. Matsumoto, J. Abe and S. Morita, 2009. Feasibility study on the application of rhizosphere microflora of rice for the biohydrogen production from wasted bread. Int. J. Hydrogen Energy, 34: 1735-1743. DOI: 10.1016/j.ijhydene.2008.12.060

Ehrmann, M.A., M.R.A. Müller and R.F. Vogel, 2003. Molecular analysis of sourdough reveals Lactobacillus mindensis sp. nov. Int. J. Syst. Evolut. Microbiol., 53: 7-13. DOI: 10.1099/ijs.0.02202-0

FAO, 2012. Towards the future we want: End hunger and make the transition to sustainable agricultural and food systems. Food and Agriculture Organization of the United States, Rome, Italy.

Fujimura, S., A. Watanabe, K. Kimura and M. Kaji, 2012. Probiotic mechanism of Lactobacillus gasseri OLL2716 Strain against Helicobacter pylori. J. Clin. Microbiol., 50: 1134-1136. DOI: 10.1128/JCM.06262-11
Ganeden BC 30 Probiotics, 2015. Ganeden BC 30 is an amazing probiotic used in food and beverages.

Ganzle, M.G., M. Ehmann and W.P. Hammes, 1998. Modeling of growth of Lactobacillus sanfranciscensis and Candida milleri in response to process parameters of sourdough fermentation. Applied Environ. Microbiol., 64: 2616-2623.

Hansen, A. and P. Schieberle, 2005. Generation of aroma compounds during sourdough fermentation: Applied and fundamental aspects. Trends Food Sci. Technol., 16: 85-94. DOI: $10.1016 /$ j.tifs.2004.03.007

Holzapfel, W.H., P. Haberer, R. Geisen, J. Björkroth and U. Schillinger, 2001. Taxonomy and important features of probiotic microorganisms in food and nutrition. Am. J. Clin. Nutrit., 73: 365s-373s. PMID: 11157343

Hugenholtz, J. and E.J. Smid, 2002. Nutraceutical production with food-grade microorganisms. Curr. Opin. Biotechnol., 13: 497-507.

DOI: 10.1016/S0958-1669(02)00367-1

Jo Panyko, 2015. Bifidobacterium bifidum-A Common Probiotic Bacteria with Uncommon Health Benefits. Power of Probiotics, Jo Panyko.

Kawa-Rygielska, J. and W. Petrzak, 2011. Utilization of waste bread for bioethanol production. Zywnosc-Nauka Technol. Jakosc, 18: 105-118.

Kelesidis, T. and C. Pothoulakis, 2012. Efficacy and safety of the probiotic Saccharomyces boulardii for the prevention and therapy of gastrointestinal disorders. Therapeutic Adv. Gastroenterol., 5: 111-125. DOI: $10.1177 / 1756283$ X11428502

Knorr, D., 1998. Technology aspects related to microorganisms in functional foods. Trends Food Sci. Technol., 9: 295-306. DOI: 10.1016/S0924-2244(98)00051-X

Kosseva, M.R., 2009. Processing of Food Wastes. In: Advances in Food and Nutrition Research, L.T. Steve (Ed.), Academic Press, pp: 57-136.

Kosseva, M.R., 2013. Chapter 5-Recovery of Commodities from Food Wastes Using SolidState Fermentation. In: Food Industry Wastes, M.R.K. Webb (Ed.), San Diego, Academic Press, pp: 77-102.

Kumar, J.V., R. Mathew and A. Shahbazi, 1998. Bioconversion of solid food wastes to ethanol. Analyst, 123: 497-502. DOI: 10.1039/A706088B

Leroy, F. and L. De Vuyst, 2004. Lactic acid bacteria as functional starter cultures for the food fermentation industry. Trends Food Sci. Technol., 15: 67-78. DOI: 10.1016/j.tifs.2003.09.004

Leung, C.C.J., A.S.Y. Cheung, A.Y.Z. Zhang, K.F. Lam and C.S.K. Lin, 2012. Utilisation of waste bread for fermentative succinic acid production. Biochem. Eng. J., 65: 10-15. DOI: $10.1016 /$ j.bej.2012.03.010 
Maeda, S., S. Imashiro, T. Amagai and T. Harada, 2004. Feed production from wastes of bakery products Kanagawa Prefecture, Japan. Ishikawajima Kensa Keisoku Co. Ltd, Japan.

Martin, J.E., 1984. Conversion of bakery waste into ethanol. Energy Citations Database.

Mekjinda, N. and R.J. Ritchie, 2015. Breakdown of food waste by anaerobic fermentation and nonoxygen producing photosynthesis using a photosynthetic bacterium. Waste Manage., 35: 199-206. DOI: 10.1016/j.wasman.2014.10.018

Melikoglu, M., C.S.K. Lin and C. Webb, 2013. Kinetic studies on the multi-enzyme solution produced via solid state fermentation of waste bread by Aspergillus awamori. Biochem. Eng. J., 80: 76-82. DOI: $10.1016 /$ j.bej.2013.09.016

Melikoglu, M. and C. Webb, 2013. Use of Waste Bread to Produce Fermentation Products. In: Food Industry Wastes: Assessment and Recuperation of Commodities, Kosseva, M.R. and C. Webb (Eds.), Academic Press, Amsterdam, ISBN-10: 0123919282, pp: 63-76.

Meuser, F., 1998. Process for recycling bakery products, more specially rests of bread and bread remainders.

Menge, B.A., J. Lubchenco, S.D. Gaines and L.R. Ashkenas, 1986. A test of the Menge-Sutherland model of community organization in a tropical rocky intertidal food web. Oecologia, 71: 75-89. DOI: 10.1007/BF00377324

Murase, Y. and A. Yoshino, 2005. Enzymic preparation of sugar solution from starch waste by decantation.

Nakano, M. and S. Yoshida, 1977. Syrup production from bread waste by fermentation. Jpn. Kokai Tokkyo Koho.

NS, 1999. Scientific concepts of functional foods in Europe consensus document. Br. J. Nutr., 81: S1-S27. DOI: 10.1017/S0007114599000471

Oda, Y., B.S. Park, K.H. Moon and K. Tonomura, 1997. Recycling of bakery wastes using an amylolytic lactic acid bacterium. Bioresour. Technol., 60: 101-106.

DOI: 10.1016/S0960-8524(97)00008-4

Olempska-Beer, Z.S., R.I. Merker, M.D. Ditto and M.J. DiNovi, 2006. Food-processing enzymes from recombinant microorganisms-a review. Regul. Toxicol. Pharm., 45: 144-158. DOI: 10.1016/j.yrtph.2006.05.001

Peñas, E., M. Diana, J. Frias, J. Quílez and C. Martínez-Villaluenga, 2015. A multistrategic approach in the development of sourdough bread targeted towards blood pressure reduction. Plant Foods Hum. Nutrit., 70: 97-103.

DOI: $10.1007 / \mathrm{s} 11130-015-0469-6$
Perricone, M., A. Bevilacqua, M.R. Corbo and M. Sinigaglia, 2014. Technological characterization and probiotic traits of yeasts isolated from Altamura sourdough to select promising microorganisms as functional starter cultures for cereal-based products. Food Microbiol., 38: 26-35. DOI: 10.1016/j.fm.2013.08.006

Pham, T.P.T., R. Kaushik, G.K. Parshetti, R. Mahmood and R. Balasubramanian, 2015. Food waste-toenergy conversion technologies: Current status and future directions. Waste Manage., 38: 399-408. DOI: 10.1016/j.wasman.2014.12.004

Rick Swartzburg, 2009. Probiotic.Org. http://www.probiotic.org/lactobacillusplantarum.htm

Salim-ur-Rehman, A. Paterson and J.R. Piggott, 2006. Flavour in sourdough breads: A review. Trends Food Sci. Technol., 17: 557-566. DOI: $10.1016 /$ j.tifs.2006.03.006

Schwab, C., M. Mastrangelo, A. Corsetti and M. Gänzle, 2008. Formation of oligosaccharides and polysaccharides by Lactobacillus reuteri LTH5448 and Weissella cibaria 10M in Sorghum Sourdoughs. Cereal Chem. J., 85: 679-684. DOI: 10.1094/CCHEM-85-5-0679

SIN, 2015. New campaign tackles $\$ 870$ million scandal, Taranaki regional council, press release. Scoop Independent News.

Skory, C.D., 2004. Lactic acid production by Rhizopus oryzae transformants with modified lactate dehydrogenase activity. Applied Microbiol. Biotechnol., 64: 237-242. DOI: $10.1007 / \mathrm{s} 00253-003-1480-7$

Smith, A. and C.L. Jones, 2012. Probiotics: Sources, Types and Health Benefits. 1st Edn., Nova Science Publishers, Incorporated, New York, ISBN-10: 1619426919, pp: 259.

Subramaniyam, R. and R. Vimala, 2012. Solid state and submerged fermentation for the production of bioactive substances: A comparative study. Int. J. Sci. Nat., 3: 480-486.

Sybesma, W., M. Starrenburg, M. Kleerebezem, I. Mierau and W.M. De Vos et al., 2003. Increased production of folate by metabolic engineering of Lactococcus lactis. Applied Environ. Microbiol., 69: 3069-3076. DOI: 10.1128/AEM.69.6.3069-3076.2003

Uçkun Kiran, E., A.P. Trzcinski and Y. Liu, 2015. Enhancing the hydrolysis and methane production potential of mixed food waste by an effective enzymatic pretreatment. Bioresour. Technol., 183: 47-52. DOI: 10.1016/j.biortech.2015.02.033

Uçkun Kiran, E., A.P. Trzcinski, W.J. Ng and Y. Liu, 2014. Bioconversion of food waste to energy: A review. Fuel, 134: 389-399. DOI: 10.1016/j.fuel.2014.05.074 
Van der Aa Kühle, A., K. Skovgaard and L. Jespersen, 2005. In vitro screening of probiotic properties of Saccharomyces cerevisiae var. boulardii and foodborne Saccharomyces cerevisiae strains. Int. J. Food Microbiol., 101: 29-39.

DOI: $10.1016 /$ j.ijfoodmicro.2004.10.039

Vancanneyt, M., P. Neysens, M. De Wachter, K. Engelbeen and C. Snauwaert et al., 2005. Lactobacillus acidifarinae sp. nov. and Lactobacillus zymae sp. nov., from wheat sourdoughs. Int. J. Syst. Evol. Microbiol., 55: 615-620.

DOI: 10.1099/ijs.0.63274-0

Vigentini, I., D. Antoniani, L. Roscini, A. Comasio and S. Galafassi et al., 2014. Candida milleri species reveals intraspecific genetic and metabolic polymorphisms. Food Microbiol., 42: 72-81. DOI: $10.1016 / \mathrm{j} . \mathrm{fm} .2014 .02 .011$

WRT, 2011. Waiheke Resource Trust. http://wrt.org.nz/take-action/homes/food/reducinghousehold-food-was

Waste MINZ, 2015. New Zealand Food Waste Audits: Waste Not. Consulting http: //www.wasteminz.org.nz/wpcontent/uploads/Final -1-0-New-Zealand-FoodWaste-Audit-Report-2015.pdf
Yahagi, K., T. Yamaguchi and J. Konakawa, 2003. Manufacture of industrial starch from food wastes. Kawasaki Heavy Industries, Ltd., Japan.

Yamashita, M. and K. Miwa, 2003. Method and Apparatus for treating food wastes by hydrothermal reaction. Ishikawajima-Harima Heavy Industries Co., Ltd., Japan.

Zhang, C., M.J. Brandt, C. Schwab and M.G. Gänzle, 2010. Propionic acid production by cofermentation of Lactobacillus buchneri and Lactobacillus diolivorans in sourdough. Food Microbiol., 27: 390-395. DOI: 10.1016/j.fm.2009.11.019

Zhang, S., S. Winestrand, L. Chen, D. Li and L.J. Jonsson et al., 2014. Tolerance of the nanocellulose-producing bacterium Gluconacetobacter xylinus to lignocellulosederived acids and aldehydes. J. Agric. Food Chem., 62: 9792-9799. DOI: 10.1021/jf502623s

Zheng, P., J.J. Dong, Z.H. Sun, Y. Ni and L. Fang, 2009. Fermentative production of succinic acid from straw hydrolysate by Actinobacillus succinogenes. Bioresour. Technol., 100: 2425-2429. DOI: 10.1016/j.biortech.2008.11.043 